\title{
Arenibacter echinorum sp. nov., isolated from the sea urchin Strongylocentrotus intermedius
}

\author{
Olga I. Nedashkovskaya, ${ }^{1}$ Seung Bum Kim, ${ }^{2}$ Anatoly M. Lysenko, ${ }^{3}$ \\ Kang Hyun Lee, ${ }^{4}$ Kyung Sook Bae ${ }^{4}$ and Valery V. Mikhailov ${ }^{1}$
}

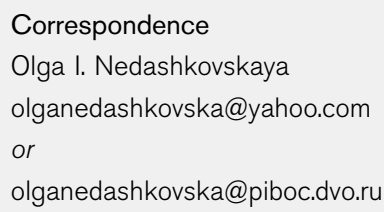

olganedashkovska@piboc.dvo.ru

\author{
${ }^{1}$ Pacific Institute of Bioorganic Chemistry of the Far-Eastern Branch of the Russian Academy \\ of Sciences, Pr. 100 Let Vladivostoku 159, 690022 Vladivostok, Russia \\ ${ }^{2}$ Department of Microbiology, Chungnam National University, 220 Gung-dong, Yuseong, \\ Daejeon 305-764, Republic of Korea \\ ${ }^{3}$ Institute of Microbiology of the Russian Academy of Sciences, Pr. 60 let October 7/2, \\ Moscow 117811, Russia \\ ${ }^{4}$ Biological Resource Center, Korea Research Institute of Bioscience and Biotechnology, \\ 52 Oun-dong, Yuseong, Daejeon 305-333, Republic of Korea
}

The genus Arenibacter, a member of the family Flavobacteriaceae (Bernardet et al., 2002), was proposed for accommodating Gram-negative, aerobic, heterotrophic and dark-orange pigmented marine bacteria, isolated from a sediment sample, from the edible holothurian Apostichopus japonicus and from the brown alga Chorda filum (Ivanova et al., 2001). Recently, the description of the genus Arenibacter was emended to include new data on gliding motility and halotolerance (Nedashkovskaya et al., 2006). To date, the genus includes four species of marine bacteria, Arenibacter certesii, Arenibacter latericius, Arenibacter palladensis and Arenibacter troitsensis (Ivanova et al., 2001; Nedashkovskaya et al., 2003, 2004, 2006).

During a taxonomic survey of microbiota of sea urchins, strains KMM $6032^{\mathrm{T}}$ and KMM 6047 were isolated from a sea urchin Strongylocentrotus intermedius collected in the Troitsa Bay, Gulf of Peter the Great, East Sea. For strain isolation, $0.1 \mathrm{ml}$ homogenates of the sea urchin tissues was transferred onto plates of marine agar 2216 (Difco). After primary isolation and purification, strains were cultivated

The GenBank/EMBL/DDBJ accession numbers for the 16S rRNA gene sequences of strains $\mathrm{KMM} 6032^{\top}$ and $\mathrm{KMM} 6047$ are EF536748 and EF536749, respectively. at $28{ }^{\circ} \mathrm{C}$ on the same medium and stored at $-80{ }^{\circ} \mathrm{C}$ in marine broth (Difco) supplemented with $20 \%$ (v/v) glycerol. The two novel sea urchin isolates were studied using a polyphasic taxonomy approach. Phylogenetic analysis based on $16 \mathrm{~S}$ rRNA gene sequences indicated that the sea urchin isolates formed a distinct branch within the genus Arenibacter. On the basis of the data obtained, we assigned the two isolates to a novel species of the genus Arenibacter, for which the name Arenibacter echinorum sp. nov. is proposed.

The phylogenetic position of strains $\mathrm{KMM} 6032^{\mathrm{T}}$ and KMM 6047 was determined from their almost-complete 16S rRNA gene sequences (1431 and $1430 \mathrm{bp}$, respectively). Genomic DNA extraction, PCR and sequencing of $16 \mathrm{~S}$ rRNA genes were performed by using previously described procedures (Cho et al., 2006). The sequences obtained were aligned with those of representative members of selected genera belonging to the family Flavobacteriaceae by using PHYDIT version 3.1 (http://plaza.snu.ac.kr/ jchun/phydit/). Phylogenetic trees were inferred by using suitable programs of the PHYLIP package (Felsenstein, 1993). Phylogenetic distances were calculated from the two-parameter model (Kimura, 1980), and the trees were constructed on the basis of the neighbour-joining (Saitou \& Nei, 1987), maximum- 
likelihood (Felsenstein, 1993) and maximum-parsimony (Kluge \& Farris, 1969) algorithms. Bootstrap analysis was performed with 1000 resampled datasets, using SEQBOOT and CONSENSE programs of the PHYLIP package.

Phylogenetic analysis revealed that strains $\mathrm{KMM} 6032^{\mathrm{T}}$ and KMM 6047 were members of the family Flavobacteriaceae and formed a distinct branch within the genus Arenibacter (Fig. 1). The two isolates shared $99.9 \% 16 \mathrm{~S}$ rRNA gene sequence similarity and the levels of sequence similarity between strains KMM $6032^{\mathrm{T}}$ and KMM 6047 and A. certesii KMM $3941^{\mathrm{T}}$, A. latericius KMM $426^{\mathrm{T}}$, A. palladensis $\mathrm{KMM}$ $3961^{\mathrm{T}}$ and $A$. troitsensis $\mathrm{KMM} 3674^{\mathrm{T}}$ were $94.6-94.7$, 94.594.6, 98.8-98.9 and $98.8 \%$, respectively.

DNA was isolated by the method of Marmur (1961) and the DNA $\mathrm{G}+\mathrm{C}$ content was determined by using the thermal denaturation method (Marmur \& Doty, 1962). The DNA G + C contents of strains KMM $6032^{\mathrm{T}}$ and KMM 6047 were 40.0 and $39.2 \mathrm{~mol} \%$, respectively. DNA-DNA

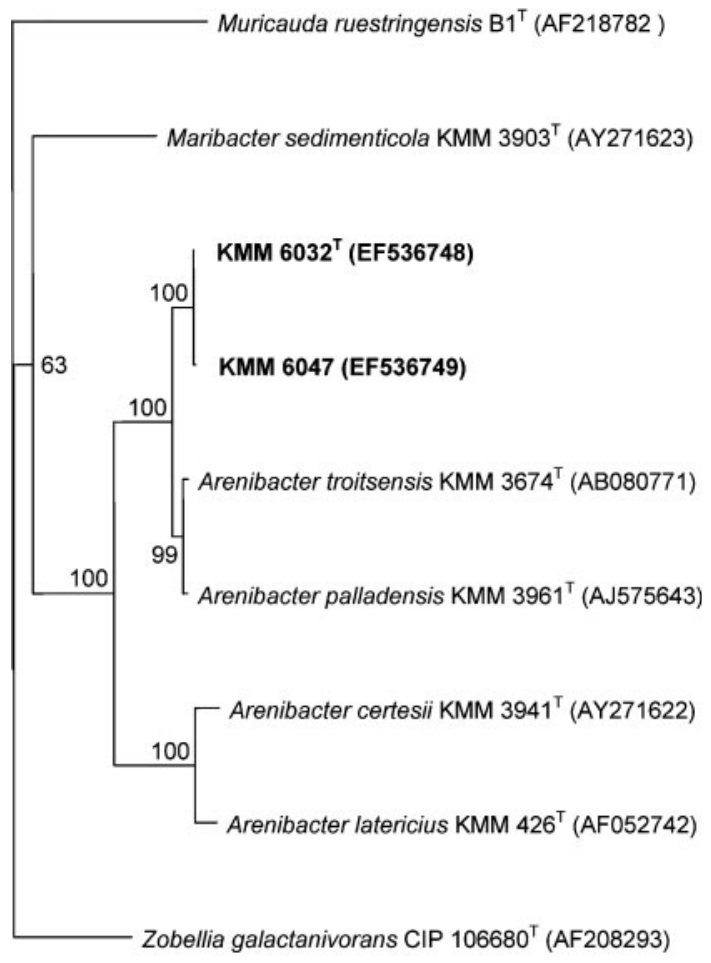

$\underline{0.01}$

Fig. 1. Phylogenetic tree of Arenibacter species and related taxa based on the 16S rRNA gene sequences. The tree was constructed using Kimura's two-parameter model and the neighbour-joining algorithm. Identical tree topologies were also obtained using the maximum-likelihood and maximum-parsimony algorithms. The numbers at nodes indicate the levels of bootstrap support (\%) when $>50$. Bar, 0.01 nucleotide substitutions per position. hybridization was performed spectrophotometrically and initial renaturation rates were recorded as described by De Ley et al. (1970). The level of DNA-DNA reassociation between strains KMM $6032^{\mathrm{T}}$ and KMM 6047 was $96 \%$, demonstrating that the two novel isolates belong to the same species according to Wayne et al. (1987). The levels of DNA-DNA binding between strain KMM $6032^{\mathrm{T}}$ and $A$. palladensis $\mathrm{KMM} 3961^{\mathrm{T}}$ and A. troitsensis $\mathrm{KMM} 3674^{\mathrm{T}}$ were 34 and $40 \%$, respectively. Based on these data, the sea urchin isolates can be affiliated to the genus Arenibacter as a distinct and novel species.

In order to determine its whole-cell fatty acid profile, strain KMM $6032^{\mathrm{T}}$ was grown at $25{ }^{\circ} \mathrm{C}$ for $48 \mathrm{~h}$ on marine agar 2216 (Difco). The analysis of fatty acid methyl esters was carried out according to the standard protocol of the Microbial Identification System (Microbial ID). The predominant cellular fatty acids of strain KMM $6032^{\mathrm{T}}$ were the straight-chain unsaturated and unsaturated and branched-chain saturated and unsaturated fatty acids iso- $\mathrm{C}_{15: 1}$, iso- $\mathrm{C}_{15: 0}, \mathrm{C}_{15: 0}, \mathrm{C}_{15: 1} \omega 6 c$, iso- $\mathrm{C}_{15: 0} 3-\mathrm{OH}$, iso- $\mathrm{C}_{17: 1} \omega 9 c$, iso- $\mathrm{C}_{17: 0} 3-\mathrm{OH}$ and summed feature 3 (comprising iso- $\mathrm{C}_{15: 0} 2-\mathrm{OH}$ and/or $\mathrm{C}_{16: 1} \omega 7 c$ ) (Table 1). The fatty acid composition of strain $\mathrm{KMM} 6032^{\mathrm{T}}$ is in accordance with those reported for the species of the genus Arenibacter (Nedashkovskaya et al., 2006).

Physiological and biochemical properties of strains KMM $6032^{\mathrm{T}}$ and $\mathrm{KMM} 6047$ were examined as described by Nedashkovskaya et al. $(2003,2004)$ and using API 20E, API 20NE and API ZYM galleries (bioMérieux) and the Biolog GN2 Microplate system according to the manufacturer's instructions.

Physiological, morphological and biochemical characteristics of the strains studied are listed in the species description and in Table 2. Strains $\mathrm{KMM} 6032^{\mathrm{T}}$ and KMM 6047 had many phenotypic features in common with the Arenibacter species (Table 2): they were aerobic, rod-shaped and dark-orange pigmented organisms, producing oxidase, catalase and alkaline phosphatase. However, the novel isolates could be distinguished from described Arenibacter species by acetoin production, by the absence of $\alpha$-chymotrypsin activity and the ability to utilize citrate, malate and mannitol. Combinations of several phenotypic traits may be used for the discrimination of strains $\mathrm{KMM} 6032^{\mathrm{T}}$ and $\mathrm{KMM} 6047$ from other Arenibacter species (Table 2). The novel isolates differ from their close phylogenetic neighbour, A. palladensis, by their inability to grow with $10 \% \mathrm{NaCl}$, to form acid from D-galactose and $\mathrm{N}$-acetyl-D-glucosamine, and to produce lipase $(\mathrm{C} 14)$. The isolates are motile by gliding, they grow without $\mathrm{NaCl}$ or seawater and with $8 \% \mathrm{NaCl}$, and oxidize D-glucose, D-melibiose, L-rhamnose and DL-xylose, in contrast with their other close relative, A. troitsensis (Table 2). Gliding motility, requirement of $\mathrm{Na}^{+}$ions for growth, nitrate reduction, urea degradation, acid production from D-galactose and DL-xylose, and chymotrypsin and $\beta$-glucuronidase activities clearly differentiate the 
Table 1. Cellular fatty acid composition (\%) of Arenibacter species

Taxa: 1, A. echinorum KMM $6032^{\mathrm{T}}$; 2, A. certesii $\mathrm{KMM} 3941^{\mathrm{T}}$; 3, A. latericius (four strains; results for the type strain in parentheses); 4, A. palladensis $\mathrm{KMM} 3961^{\mathrm{T}}$; 5, A. troitsensis $\mathrm{KMM} 3674^{\mathrm{T}}$. All strains were cultivated under the same conditions. Only those fatty acids amounting to more than $1.0 \%$ in one of the strains listed are indicated. Summed feature 3 consisted of one or more of the following fatty acids which could not be separated by the Microbial Identification System: iso- $\mathrm{C}_{15: 0} 2-\mathrm{OH}$ and/or $\mathrm{C}_{16: 1} \omega 7 c$.

\begin{tabular}{|c|c|c|c|c|c|}
\hline Fatty acid & 1 & 2 & 3 & 4 & 5 \\
\hline iso- $\mathrm{C}_{15: 0}$ & 6.4 & 7.7 & $6.9-15.8(8.1)^{*}$ & 8.7 & 6.8 \\
\hline anteiso- $\mathrm{C}_{15: 0}$ & 1.8 & 6.3 & $4.8-13.5(9.3)$ & 3.3 & 3.2 \\
\hline iso- $\mathrm{C}_{15: 1}$ & 13.1 & 7.2 & $4.9-14.0(14.0)$ & 12.7 & 12.2 \\
\hline anteiso- $\mathrm{C}_{15: 1}$ & 0.5 & 0.8 & $0.6-2.9(2.9)$ & 0.5 & 0.6 \\
\hline $\mathrm{C}_{15: 0}$ & 22.0 & 11.5 & $4.2-16.0(14.2)$ & 15.0 & 13.6 \\
\hline $\mathrm{C}_{15: 1} \omega 6 c$ & 4.2 & 1.9 & $1.0-2.3(2.3)$ & 2.6 & 1.2 \\
\hline iso- $\mathrm{C}_{16: 0}$ & 1.0 & 1.7 & $0.5-1.3(0.5)$ & 0.2 & 0.3 \\
\hline $\mathrm{C}_{16: 0}$ & 0.6 & 1.0 & $1.1-2.7(1.9)$ & 0.6 & 1.5 \\
\hline iso- $\mathrm{C}_{17: 1} \omega 9 c$ & 3.9 & 4.7 & $2.2-4.6(2.9)$ & 4.0 & 5.3 \\
\hline $\mathrm{C}_{17: 1} \omega 8 c$ & 1.1 & 2.4 & $0.5-2.0$ & 0.5 & 0.9 \\
\hline $\mathrm{C}_{17: 1} \omega 6 c$ & 2.9 & 3.0 & $0.7-2.9(2.4)$ & 1.4 & 1.1 \\
\hline $\mathrm{C}_{15: 0} 2-\mathrm{OH}$ & 0.6 & 0.6 & $0.7-1.0(0.6)$ & 0.4 & 0.4 \\
\hline iso- $\mathrm{C}_{15: 0} 3-\mathrm{OH}$ & 3.5 & 3.5 & $4.6-5.7(5.6)$ & 5.3 & 5.1 \\
\hline $\mathrm{C}_{15: 0} 3-\mathrm{OH}$ & 2.0 & 0.6 & $0.0-1.4(0)$ & 2.2 & 1.6 \\
\hline iso- $\mathrm{C}_{16: 0} 3-\mathrm{OH}$ & 1.0 & 7.2 & $2.1-5.7(2.1)$ & 1.6 & 2.2 \\
\hline $\mathrm{C}_{16: 0} 3-\mathrm{OH}$ & 1.0 & 0.8 & $0.6-1.3(1.3)$ & 2.0 & 2.2 \\
\hline iso- $\mathrm{C}_{17: 0} 3-\mathrm{OH}$ & 10.5 & 13.3 & $6.9-14.4(6.9)$ & 17.4 & 21.9 \\
\hline $\mathrm{C}_{17: 0} 2-\mathrm{OH}$ & 0.3 & 3.8 & $2.1-5.1(2.1)$ & 1.0 & 1.7 \\
\hline Summed feature 3 & 10.7 & 13.5 & $9.8-11.9(9.8)$ & 11.1 & 9.6 \\
\hline
\end{tabular}

${ }^{*}$ The values of fatty acids for Arenibacter latericius $\mathrm{KMM} 426^{\mathrm{T}}$ are indicated in parentheses.

novel isolates from strains of $A$. latericius and $A$. certesii (Table 2).

Differentiating phenotypic characteristics (Table 2) taken together with genomic distinctiveness support the discrimination of the strains studied from recognized Arenibacter species. Consequently, strains KMM $6032^{\mathrm{T}}$ and KMM 6047 can be considered to be members of a novel species of the genus Arenibacter, for which the name Arenibacter echinorum sp. nov. is proposed.

\section{Description of Arenibacter echinorum sp. nov.}

Arenibacter echinorum (e.chi.no'rum. L. gen. pl. n. echinorum of sea urchins; N.L. gen. n. echinorum bacterium isolated from sea urchins).

The main characteristics are the same as those given for the genus. In addition, cells range from 0.4 to $0.5 \mu \mathrm{m}$ in width and from 1.5 to $2.7 \mu \mathrm{m}$ in length and move by means of gliding. On marine agar, colonies are $2-4 \mathrm{~mm}$ in diameter, circular, convex with entire edges and dark-orange in colour. Growth is observed at $4-35{ }^{\circ} \mathrm{C}$ and with $0-8 \%$ $\mathrm{NaCl}$. Optimum growth occurs at $24-26{ }^{\circ} \mathrm{C}$ and with $1 \%$ $\mathrm{NaCl}$. Tween 40 is hydrolysed. Hydrolysis of Tween 20 is strain-dependent. Agar, casein, gelatin, alginate, starch, Tween 80, DNA, urea, cellulose (CM-cellulose and filter paper) and chitin are not decomposed. Acid is produced from D-cellobiose, L-fucose, D-glucose, D-lactose, maltose, D-melibiose, L-rhamnose, sucrose, DL-xylose and amygdalin, but not from L-arabinose, D-galactose, L-sorbose, $\mathrm{N}$ acetyl-D-glucosamine, citrate, adonitol, dulcitol, glycerol, inositol or mannitol. Acid production from D-raffinose is strain-dependent. L-Arabinose, glucose, lactose, D-mannose, sucrose, $\mathrm{N}$-acetyl-D-glucosamine, citrate, malate and mannitol are utilized, but inositol and sorbitol are not. Nitrate is not reduced. Acetoin (Voges-Proskauer reaction) is produced, but indole and $\mathrm{H}_{2} \mathrm{~S}$ are not. Arginine dihydrolase, lysine- and ornithine-decarboxylases and tryptophan deaminase activities are absent. In API ZYM strips, esterase lipase (C8), leucine-, valine-, cystinearylamidases, trypsin, acid phosphatase, naphthol-AS-BIphosphohydrolase, $\alpha$ - and $\beta$-galactosidases, $\alpha$ - and $\beta$ glucosidases, $\quad \beta$-glucuronidase, $N$-acetyl- $\beta$-glucosaminidase, $\alpha$-mannosidase and $\alpha$-fucosidase activities are present, but lipase (C14) and $\alpha$-chymotrypsin activities are absent. Esterase (C4) activity is strain-dependent. In Biolog GN2 Microplates, dextrin, gentiobiose, $\alpha$-lactose, $\alpha$-D-lactose, lactulose, D-raffinose, trehalose, turanose, methyl pyruvate and DL-lactic acid are utilized. Utilization of $\alpha$-D-glucose, methyl $\beta$-D-glucoside and $\alpha$-ketobutyric acid is straindependent. The following compounds are not utilized: $\alpha$ cyclodextrin, D-fructose, D-galactose, Tween 80, adonitol, D-arabitol, glycogen, $N$-acetyl-D-glucosamine, $N$-acetyl-Dgalactosamine, L-glutamic acid, $\alpha$-D-glucose 1-phosphate, $i$-erythritol, myo-inositol, D-psicose, xylitol, mono-methylsuccinate, acetic acid, citric acid, formic acid, D-galactonic acid lactone, D-galacturonic acid, D-gluconic acid, Dglucosaminic acid, D-glucuronic acid, L-glutamic acid, $\alpha$ and $\beta$-hydroxybutyric acids, $p$-hydroxyphenylacetic acid, itaconic acid, $\alpha$-ketoglutaric acid, $\alpha$-ketovaleric acid, malonic acid, propionic acid, quinic acid, D-saccharic acid, sebacic acid, succinic acid, bromosuccinic acid, succinamic acid, glucuronamide, alaninamide, D-alanine, L-alanyl glycine, L-asparagine, L-aspartic acid, glycyl L-aspartic acid, glycyl L-glutamic acid, L-histidine, L-proline, hydroxy-Lproline, L-leucine, L-ornithine, L-threonine, L-phenylalanine, L-pyroglutamic acid, D- and L-serine, DL-carnitine, $\gamma$-aminobutyric acid, uronic acid, inosine, uridine, thymidine, phenylethylamine, putrescine, 2-aminoethanol, 2,3butanediol, glycerol, DL- $\alpha$-glycerol phosphate and D-glucose 6-phosphate. Susceptible to chloramphenicol, erythromycin, lincomycin and oleandomycin. In addition, the type strain is susceptible to doxycycline, streptomycin and tetracycline. Resistant to ampicillin, benzylpenicillin, gentamicin, kanamycin, carbenicillin, neomycin and polymyxin B. The predominant fatty acids of strain KMM $6032^{\mathrm{T}}$ are the straight-chain saturated, and unsaturated and branched-chain unsaturated fatty acids $\mathrm{C}_{15: 0}(22.0 \%)$, iso$\mathrm{C}_{15: 1}(13.1 \%)$, summed feature 3 (10.7\%; comprising 
Table 2. Phenotypic characteristics of Arenibacter echinorum sp. nov. and other Arenibacter species

Taxa: 1, A. echinorum KMM 6032 ${ }^{\mathrm{T}}$ and $\mathrm{KMM} 6047 ; 2$, A. certesii $\mathrm{KMM} 3941^{\mathrm{T}}$; 3, A. latericius (five strains); 4, A. palladensis (three strains); 5, A. troitsensis $\mathrm{KMM} 3674^{\mathrm{T}}$. All of the strains were positive for the following characteristics: respiratory-type metabolism; oxidase, catalase, acid and alkaline phosphatases, $\alpha$ - and $\beta$-galactosidases, $\alpha$ - and $\beta$-glucosidases, $N$-acetyl- $\beta$-glucosaminidase, esterase lipase (C8), leucine-, valine- and cystine-arylamidases, trypsin, naphtholAS-BI-phosphohydrolase, $\alpha$-mannosidase and $\alpha$-fucosidase activities; growth with $1-6 \% \mathrm{NaCl}$ and at $10-32{ }^{\circ} \mathrm{C}$; acid formation from maltose, D-cellobiose and sucrose; utilization of L-arabinose, Dglucose, D-lactose and D-mannose; susceptibility to lincomycin and resistance to kanamycin, benzylpenicillin, gentamicin, neomycin and polymyxin B. All of the strains were negative for the following characteristics: requirement for organic growth factors; arginine dihydrolase, lysine- and ornithine-decarboxylases and tryptophan deaminase activities; production of flexirubin-type pigments and indole; degradation of agar, casein, starch, alginic acids, cellulose (CM-cellulose and filter paper) and chitin; acid production from Larabinose, L-sorbose, adonitol, dulcitol, inositol, mannitol, fumarate and citrate; utilization of adonitol, inositol and sorbitol. + , Positive; -, negative; v, variable $(<60 \%$ strains demonstrated positive reaction); $\mathrm{V}^{+},>60 \%$ strains showed a positive reaction; $\mathrm{V}^{-}$, $>60 \%$ strains showed a negative reaction. The reactions of the type strains are indicated in parentheses. Data from Ivanova et al. (2001), Nedashkovskaya et al. (2003, 2004, 2006) and this study.

\begin{tabular}{|c|c|c|c|c|c|}
\hline Characteristic & 1 & 2 & 3 & 4 & 5 \\
\hline Gliding motility & + & - & - & + & - \\
\hline $\mathrm{Na}^{+}$requirement for growth & - & + & + & - & + \\
\hline Nitrate reduction & - & + & + & - & + \\
\hline $\mathrm{H}_{2} \mathrm{~S}$ production & - & - & - & - & + \\
\hline Acetoin production & + & - & - & - & - \\
\hline \multicolumn{6}{|l|}{ Degradation of: } \\
\hline Gelatin & - & + & - & - & + \\
\hline Urea & - & + & + & + & - \\
\hline Tween 40 & + & - & $\mathrm{V}^{-}(-)$ & - & + \\
\hline \multicolumn{6}{|l|}{ Growth with: } \\
\hline $8 \% \mathrm{NaCl}$ & + & + & + & + & - \\
\hline $10 \% \mathrm{NaCl}$ & - & + & - & + & - \\
\hline Growth at $42{ }^{\circ} \mathrm{C}$ & - & + & + & - & + \\
\hline \multicolumn{6}{|l|}{ Acid production from: } \\
\hline D-Galactose & - & + & + & - & - \\
\hline D-Glucose & + & - & + & + & - \\
\hline D-Lactose & + & - & + & + & + \\
\hline D-Melibiose & + & - & $\mathrm{V}^{+}(+)$ & - & - \\
\hline D-Raffinose & $\mathrm{v}(+)$ & - & + & - & + \\
\hline L-Rhamnose & + & - & $\mathrm{V}^{-}(+)$ & + & - \\
\hline DL-Xylose & + & - & - & + & - \\
\hline Glycerol & - & + & + & + & - \\
\hline$N$-Acetyl- $\beta$-glucosamine & - & - & $\mathrm{V}^{-}(+)$ & + & - \\
\hline $\begin{array}{l}\text { Utilization of mannitol, } \\
\text { malate, citrate }\end{array}$ & + & - & - & - & - \\
\hline \multicolumn{6}{|l|}{ Production of: } \\
\hline$\alpha$-Chymotrypsin & - & + & + & - & + \\
\hline$\beta$-Glucuronidase & + & - & - & - & + \\
\hline
\end{tabular}

\begin{tabular}{|lccccc|}
\hline Characteristic & $\mathbf{1}$ & $\mathbf{2}$ & $\mathbf{3}$ & $\mathbf{4}$ & $\mathbf{5}$ \\
\hline Susceptibility to: & & & & & \\
$\quad$ Ampicillin & - & + & + & - & - \\
Carbenicillin & - & - & + & - & - \\
Oleandomycin & + & + & + & - & + \\
Tetracycline & $\mathrm{V}(-)$ & - & - & - & + \\
DNA G+C content $(\mathrm{mol} \%)$ & $39-40$ & 38 & $37-38$ & 40 & 40 \\
\hline
\end{tabular}

iso- $\mathrm{C}_{15: 0} \quad 2-\mathrm{OH}$ and/or $\left.\mathrm{C}_{16: 1} \omega 7 c\right)$, iso- $\mathrm{C}_{17: 0} \quad 3-\mathrm{OH}$ $(10.5 \%)$, iso- $\mathrm{C}_{15: 0} \quad(6.4 \%), \mathrm{C}_{15: 1} \omega 6 c \quad(4.2 \%)$, iso$\mathrm{C}_{17: 1} \omega 9 c(3.9 \%)$ and iso- $\mathrm{C}_{15: 0} 3-\mathrm{OH}(3.5 \%)$. The DNA $\mathrm{G}+\mathrm{C}$ content is $39-40 \mathrm{~mol} \%$.

The type strain, KMM $6032^{\mathrm{T}}\left(=\mathrm{KCTC} 22013^{\mathrm{T}}=\mathrm{LMG}\right.$ $22574^{\mathrm{T}}$ ), was isolated from a sea urchin Strongylocentrotus intermedius collected in Troitsa Bay, East Sea. Another reference strain is KMM 6047 (=KCTC 22014=LMG 22582).

\section{Acknowledgements}

This research was supported by grants from the Russian Foundation for Basic Research no. 05-04-48211, from Presidium of the Russian Academy of Sciences 'Molecular and Cell Biology', from Presidium of the Far-Eastern Branch of the Russian Academy of Sciences no. 0604-96067 and from President of Russian Federation 'Scientific Schools'. K. H. L. and K.S. B. acknowledge support from the KRIBB Research Initiative Program.

\section{References}

Bernardet, J.-F., Nakagawa, Y. \& Holmes, B. (2002). Proposed minimal standards for describing new taxa of the family Flavobacteriaceae and emended description of the family. Int J Syst Evol Microbiol 52, 1049-1070.

Cho, S.-H., Han, J.-H., Seong, C. N. \& Kim, S. B. (2006). Phylogenetic diversity of acidophilic sporoactinobacteria isolated from various soils. J Microbiol 44, 600-606.

De Ley, J., Cattoir, H. \& Reynaerts, A. (1970). The quantitative measurement of DNA hybridization from renaturation rates. Eur $J$ Biochem 12, 133-142.

Felsenstein, J. (1993). PHYLIP (phylogeny inference package), version 3.5c. Distributed by the author. Department of Genome Sciences, University of Washington, Seattle, USA.

Ivanova, E. P., Nedashkovskaya, O. I., Chun, J., Lysenko, A. M., Frolova, G. M., Svetashev, V. I., Vysotskii, M. V., Mikhailov, V. V., Huq, A. \& Colwell, R. R. (2001). Arenibacter gen. nov., new genus of the family Flavobacteriaceae and description of a new species, Arenibacter latericius sp. nov. Int J Syst Evol Microbiol 51, 1987-1995.

Kimura, M. (1980). A simple method for estimating evolutionary rates of base substitutions through comparative studies of nucleotide sequences. J Mol Evol 16, 111-120.

Kluge, A. G. \& Farris, F. S. (1969). Quantitative phyletics and the evolution of anurans. Syst Zool 18, 1-32.

Marmur, J. (1961). A procedure for the isolation of deoxyribonucleic acid from microorganisms. J Mol Biol 3, 208-218.

Marmur, J. \& Doty, P. (1962). Determination of the base composition of deoxyribonucleic acid from its thermal denaturation temperature. J Mol Biol 5, 109-118. 
Nedashkovskaya, O. I., Suzuki, M., Vysotskii, M. V. \& Mikhailov, V. V. (2003). Arenibacter troitsensis sp. nov., isolated from marine bottom sediment. Int J Syst Evol Microbiol 53, 1287-1290.

Nedashkovskaya, O. I., Kim, S. B., Han, S. K., Lysenko, A. M., Mikhailov, V. V. \& Bae, K. S. (2004). Arenibacter certesii sp. nov., a novel marine bacterium isolated from the green alga Ulva fenestrata. Int J Syst Evol Microbiol 54, 1173-1176.

Nedashkovskaya, O. I., Vancanneyt, M., Cleenwerck, I., Snauwaert, C., Kim, S. B., Lysenko, A. M., Shevchenko, L. S., Lee, K. H., Park M. S. \& other authors (2006). Arenibacter palladensis sp. nov., a novel marine bacterium isolated from the green alga Ulva fenestrata, and emended description of the genus Arenibacter. Int $J$ Syst Evol Microbiol 56, 155-160.

Saitou, N. \& Nei, M. (1987). The neighbor-joining method: a new method for reconstructing phylogenetic trees. Mol Biol Evol 4, 406-425.

Wayne, L. G., Brenner, D. J., Colwell, R. R., Grimont, P. A. D., Kandler, O., Krichevsky, M. I., Moore, L. H., Moore, W. E. C., Murray, R. G. E. \& other authors (1987). International Committee on Systematic Bacteriology. Report of the ad hoc committee on reconciliation of approaches to bacterial systematics. Int J Syst Bacteriol 37, 463-464. 